$1-1-2011$

\title{
Roles of Government, Nonprofit Sector, Business and Family and Their Interaction in Democracy
}

Stuart Mendel

Cleveland State University, scmendel@cs.com

Follow this and additional works at: https://engagedscholarship.csuohio.edu/urban_facpub

Part of the Growth and Development Commons, and the Urban Studies Commons

How does access to this work benefit you? Let us know!

\section{Repository Citation}

Mendel, Stuart, "Roles of Government, Nonprofit Sector, Business and Family and Their Interaction in Democracy" (2011). All Maxine Goodman Levin School of Urban Affairs Publications. 0123381.

https://engagedscholarship.csuohio.edu/urban_facpub/381

This Contribution to Books is brought to you for free and open access by the Maxine Goodman Levin School of Urban Affairs at EngagedScholarship@CSU. It has been accepted for inclusion in All Maxine Goodman Levin School of Urban Affairs Publications by an authorized administrator of EngagedScholarship@CSU. For more information, please contact library.es@csuohio.edu. 


\section{Roles of Government, Nonprofit Sector, Business and Family and Their Interaction in Democracy}

\section{Introduction}

At last count, democracy was credited as being practiced as the formally recognized national government in 123 countries around the globe (Freedomhouse.org: Tables and Charts, 2007). In each of these places, the national character, practices and influences upon democracy is heavily influenced by the history, economy, culture, religious values and long-standing traditions of each land. For example, few would argue that there are considerable differences in the manner in which democracy is practiced in Great Britain and India; Israel and the United States; Venezuela and Germany; France and Turkey; Spain and Sri Lanka; Ukraine and Mexico. Because of the variations in place-bound democracy, it will be efficient to consider a single model that can serve as comparison for other countries of the globe. This essay will present the American model and its inter-relationships between government, business, nonprofits and the family.

This essay will define and discuss government, nonprofit sector, business and family and their interaction in American democracy. The essay will establish a context for understanding the overarching polity - all the actions that together comprise the political fabric of a community

- in the United States. It will also offer definition and insight into the distinctive American civil society, a concept whose product results from all the working of government, the nonprofit sector, business and family. Finally, the model will provide opportunity for students and scholars to establish benchmark characteristics of democracy for further comparison to other countries around the globe.

Democracy in America has been practiced in permutations of successive complexity for nearly four hundred years. It has advanced from its origins within a particular framework of 
countervailing economic, political and social forces that prized individuals and their desire for a life to pursue their own interests. It should come as no surprise the original principles serve as the foundation for the democracy in the United States of the twenty-first century. So, to understand democracy today, it is necessary to recall and analyze the origins, circumstance and principles from which American civil society arose on the North American continent.

\section{Background}

Formal institutions of government were few during the early years of European settlement of America. In the absence of an established public civil authority, the rule of law over commercial transactions, the ownership of property and the behavior of residents was governed by a combination of military court justice and private church leaders and associations of individuals united by common self-interest (Ubbelhode, 1960). These practices filled a gap arising from the slender thread of public authority in a wilderness whose isolation from the Old World traditions and rituals was exacerbated by the time it took a wooden-masted sailing ship of the late seventeenth and early eighteen century to cross the Atlantic Ocean and return with proper instructions to resolve conflict and establish order. In the absence of enforceable local government, a tradition of problem solving and decision making over the public good through local consensus took hold in which the opinion and choice of private interests with economic concerns, operations or property ownership increased in importance.

The absence of a public and formal coercive authority with the means to enforce the law stimulated affluent land-owning and enterprising residents of America to associate in the pursuit of their self-interests. We are reminded that self interests were first and foremost economic in nature. Even in the case of the "Puritans" whose arrival in America is commonly attributed to a desire to escape the religious persecution in the countries of Europe, success directly related to 
the ability of individual communities to be not only self sustaining but commercially profitable. This was certainly the case with the early Virginia settlements at Jamestown.

During the $17^{\text {th }}$ and $18^{\text {th }}$ centuries, the practice of independent decision making in colonial America was marked by two characteristics. First, that although individuals preferred to be left to their own devices, they would join together for the public good when it was in their interests to do so. Second, the presence of a vast expanse of property available to those who had the power and capacity to appropriate it from the native residents of the land offered individuals opportunities for independent wealth generation and the liberty to engage profit making enterprises as they were inclined. The notion of profit making and wealth creation to define the intention behind the use of the terms "liberty" and "freedom" that would later appear in the Constitution of the United States.

During the early to middle colonial period, democracy was local, informal and initially was less a tool of the coercive power of government, than a collaborative method of preserving the interests of individuals to exploit the opportunities for wealth in the great rough country-side. While settled communities were small and isolated by vast forests, streams and mountains, the important connections with liberal democracy resided with the individuals, their family groups and small town leaders. The leading citizens of each community were associated through their level of education and affluence. But this is not the whole story. In addition to the moral purism ascribed by early leading colonial citizens such as John Winthrop in 1630's “Model of Christian Charity" wherein small town life was cast as a shining city upon the hill in the backwoods, the founders of the nation were influenced by the philosophies of freedom of rights, equality of man and market based economic principles put forth by the classical thinkers John Locke, Edmund Burke, Adam Smith and others (Hammack, 1998). 
Looking back on these origins allows us to understand the formative seeds of democracy as political pluralism whose normative tensions among American democracy, government, business, nonprofit organizations and family yield a distinct polity and civil society. Unlike the established countries of the Old World, the tensions of governance where moderated by economic incentives in the New World that served to protect the interests of individuals by placing safeguards against, as Madison warned, "the tyranny of the majority" and that of "private factions." In public government, the doctrine of separation of powers, separation of religion from state, freedom of speech and the remaining rights declared in the U.S. Constitution limited the statutory power of public authority. At the same time, limits on private power and authority are set in place by public statute, through the market competition, and the associative organizing action individuals.

\section{The American Political Tradition and the Ecology of Games}

Democracy in middle to late colonial America incubated in an environment of little or no central authority. In place of establish regimes, bureaucracy and the military that might be found in the countries of the Old World, the values of informal private association for economic self interests, small families and communities, religion and the pragmatism of geographic isolation fashioned a private governance over public matters. Private governance rested upon a delicate balance between the rights assumed by individuals and the responsibilities required of individuals to maintain those rights for all. The combination of public and private authority bound together to nurture the best conditions possible for the acquisition of wealth and comprised what we might today consider a distinctive "civil society" (O’Connell, 2000).

The American Political Tradition arose from the early framework established during the colonial era of individual effort whose rewards were the creation of wealth with little 
interference from public authority. The sentiments behind this philosophy arose through the tug and pull of competing interests that comprise American civil society and through the thinking of the founding generation of American leaders - James Madison, Thomas Jefferson among others - who advanced the proposition that owning of property by a large number of individuals was a desirable basis for a representative government. The motivation for these "yeoman" farmers independent, self-made men - would be a collective self-interest for preserving each ones ability to earn and protect their liberty to amass wealth (Gould, 2003). Today, we recognize elements of this Tradition in the political platforms of the two major national parties, but also in the subconscious promise of freedom and liberty extended to American families that advances the potential of the individual.

Although the well-known historian Richard Hofstadter (1948) offered an influential criticism of the American Political Tradition as much more nuanced in the development of the Unites States economic, political and social structures by the nations important leaders and political figures, the Tradition offers a useful lens through which to understand the roots of democracy in this country. For one, the Tradition assigns to its public and private institutions, business activity and the nature and structure of our families, an important role in preserving the liberty to accumulate wealth. An important mechanism to stimulate and preserve this liberty, are the tensions between government, business, nonprofits and individuals that serve as a "check and balance" against perpetual unrestrained power in society.

This notion of check and balance will sound familiar and is a parallel to the well-known "separation of powers" the authors of the Constitution of the United States wrote into the document. In the usage beyond government, the tensions between government, business, nonprofits and individuals provide for trust that is the life-blood of liberal, pluralistic democracy 
and civil society. Democracy in this way of thinking obtains its character through the complex interactions - the tensions - of all the actors of polity, bound together in a competition for the creation or accumulation of wealth and the freedom to obtain wealth. Viewed through this lens, the practice of democracy depends upon a civil society characterized by engaged citizens acting toward their individual and collective self interests.

In more contemporary times the threads of connection to the earlier era of democracy is readily apparent. People in the Unites States today can surely agree that self interest is a powerful force that frames and defines our nation-hood. But Americans will also recognize that competition between individuals, associations and public authority requires a buffer to mediate points of conflict that are not resolvable if left to the government, the market, associations or the family. As Norton Long described in his important writing of the Local Community and the Ecology of Games (1958) each player in this societal competition or "games" contends to advance their own interests by using others and are in turn used to achieve the aims of others. According to Long, in the local polity over-all planning for the public good is seldom if at all, a rational process guided by a single authority. Rather, policy decisions for public resources result from an aggregate of actions by many individuals working both independently of one another but also in concert with one-another through institutions they form (Banfield and Meyerson, 1955). The blend of their actions produces a contextual mosaic which Long called an "ecology" or an unconscious operation of intertwined systems that produce predictable results.

At the core of Long's thesis are associations or communities of people brought together by common goals to which they can aspire as individuals or in collaboration with others. The goals are achieved through structured activities and calculable strategies and tactics in which the community members and others can measure their success or failure. Long called these 
competitive interactions games because the primary participants compete, keep score and win or lose based upon their ability to recognize secondary and tertiary allies and to understand the advantages and possibilities presented on a shifting playing field.

Although the primary focus of community participants is on one game, interactions between multiple games occur frequently when players of one game are compelled to use and be used by players in other games. By way of illustration, Long offered examples of the real estate developer using the banker, the banker using the civic leader, the civic leader using the faith based leader, the newspaperman and so on. At the point where bridging connections between game communities are institutionalized through formation of nonprofit organizations, players become constituents with a greater interest in keeping score. It is important to note that the interrelationships between communities comprise a system of partnership and investment resulting in derivative constituencies of each game.

The enormous upside is that individuals may become wealthy through their-own efforts in a system of democracy constructed to aid that process. Unfortunately the price paid for the potential reward of great wealth has a cruel downside for individuals: if a player fails, the government does not offer them a safety net.

Applying the ecology of games theory to democracy and public policy that shifts with changes in advances in technology and entrepreneurialism, successful outcomes will be incremental and deliberate in their progress. In the best of circumstances, the wheels of government move slowly, but deliberatively. On the other hand, unsuccessful outcomes of the ecology of games are reflected in policy blocking actions, government gridlock and the political dogmatism of entrenched interests. 


\section{Defining the Roles of Government, Business, Nonprofit Organizations and the Family in Democracy}

Democracy

Much has been written about American democracy. Historians such as Gordon S. Wood (1991) point to the eighteenth century and the American and French Revolutions as among the most noteworthy examples of radical change from nobility-based government to the emergence of the kind of representative democracy that has come to be practiced in the United States. These early examples of modern democracy differed in terms of the level of violence and disorder employed by citizens to shift from monarchial governance in the respective countries.

Nevertheless, both shared the characteristic of moving toward government that served the greater population of property owners and represented the emergence of an educated middle class of people engaged in skilled trades or business enterprise. In America, equality in democracy was established by the rule of law foremost as a way to protect the property rights and business concerns of people using representative governance by the people, for the people (Bailyn,1992).

In America, democracy drew its character from the tension of political philosophy that pit the rule of law and central authority against the more informal aspects of associational citizenship and their responsibility as individuals to participate in their own governance. Invariably this tension arose in anticipation of individuals who might use the tools of public governance for their own self-interest. James Madison warned of this tendency of in Federalist Papers No 10, where he noted the danger of parties who were at the same time judges in their own causes. Most would agree that the intention of the nation's founders was to place barriers to deter government from entering into oppressive action and expensive ventures. As a result, the separation of powers was an important element of the U.S. Constitution that positioned 
government to concentrate its work on maintaining favorable conditions for the development and expansion of business enterprise.

Democracy's relationship with government in the United States is one of many tensions or as Robert Dahl wrote, conflict arising through public process and private interest (1985). Tension is necessary to nurture and safeguard trust among the broader community because without it, no can be trusted to act in anything but their own self interests. For example, enacting legislation is a deliberative process requiring time and compromise provides opportunity for all citizens to be made aware of the proceedings. Slowing the deliberative process also protects the private interests that may then take action through the function of advocacy and associational interest groups. On the other hand, private interest groups must be monitored by government and other private interest groups to avoid their undue influence and interference in the business of government.

The relationship between government and democracy is a union of actor and process. Government establishes the legal framework and mechanism for establishing an environment favorable to individuals engaged in creating and preserving wealth. Democracy provides a process through which individuals are bound to follow laws and participate in government. Intermediary organizations we have come to call nonprofits, facilitate the differences between the interests of government and business, and the processes of democracy with the interests of individuals. In perpetuating tension among government, business, nonprofits and the individuals, democracy is preserved and enhanced in a manner that protects the rights and freedoms of individuals.

\section{Liberal tradition in American democracy}

Among the more important contributions to our understanding of liberal democracy in the 
United States is the thinking offered by the consensus era scholar Louis Hartz in The Liberal Tradition in America (1955). Hartz explained that the classical liberalism which embraces capitalism as an organizing principle and proposed by the seventeenth century philosopher John Locke, contributed to the long standing and exceptional character of democracy in America. Locke's influence on the authors of the U.S Constitution was reflected in the provisions for separation of church and state, separation of powers within government and the linkage of property ownership to economy and as arising from the labor of individuals (Ashcraft, 1986). The prevailing view was that the American colonies did not have to overthrow a feudal social and economic class system (Hartz, 1955). In fact, some argue that the Mayflower Compact established the tone in the New World for civil agreements and resolutions for disagreement as it constituted government through written contract (Lowi, 1995). De Tocqueville observations in the 1830s supported this reasoning for the relative non-violent nature of the American revolution as compared to the French (and by extension the Russian Revolution in the early twentieth century.

Hartz's treatment of the subject was among the first to point out that liberalism in American democracy arose through the work of individuals as a propertied but class-less, polity. This tended to support the framework of the American Political Tradition and the use of liberal democracy as a way to manage tensions and change in society. The considerable criticism of Hartz by subsequent scholars did not refute his supposition that liberal democracy was present, expressed in the manner he portrayed or influenced the greater society and political character of the United States. Rather, opponents to Hartz focused on his assertions that the American populace shared a uniformity of thought, social status and access to the economic spoils of their labors. In other words, the criticism was not about liberal democracy as a feature of American 
polity, but that in its practice, liberal democracy was not accessibility to women and racial and ethnic minorities who did not participate in or benefit from it (Nackenhoff, 2005 \& Smith, 1993).

\section{Government}

Government's role in American democracy is a matter of practical application. In granting rights to citizens and expediting their participation in the process of representation government provides the institutional space to practice democracy. Government also establishes the conditions by which citizens can achieve their self-interests within the bounds of laws. But government's role is also idealistic in respect that its actions must generate trust by citizens of a nation in the institutions of government and in their private interactions with businesses, nonprofits and between individuals.

The scholarly literature on "government" is vast. Even so, a single standard definition of "government" is difficult to establish. For example, Websters on-line dictionary offers six distinctive definitions, each using the term "govern" in its definition of government. Among them are: 1) the body of persons that constitutes the governing authority of a political unit or organization: as the officials comprising the governing body of a political unit and constituting the organization as an active agency; 2) a small group of persons holding simultaneously the principal political executive offices of a nation or other political unit and being responsible for the direction and supervision of public affairs.

Another on-line source, Wiki-pedia a popular cultural encyclopedia unmonitored by formal scholarly authority with millions of articles contributed collaboratively, defines government as: "the body within an organization that has authority and function to make and the power to enforce laws, regulations, or rules. Typically, government refers to a civil government that is local, provincial, or national. However, commercial, academic, religious, or 
other formal organizations are also governed by internal bodies that may be considered as comprising a "private" government.

The classical thinker Thomas Hobbs, who predated John Locke by fifty years, considered government as a way to order society in a manner so that a single authority would make decisions to the benefit of all. In Hobbs' world, government was best provided by an authoritarian sovereign as the alternative was civil war and chaos, characteristics he felt were "natural" to man. Max Weber, an important nineteenth century German social theorist considered the coercive power of government - its ability to control the behavior of others - as its most distinctive characteristic (Beetham,1991).

More recently, Theordore Lowi explained that government in America was established as a contract between the framers of the U.S Constitution - a land owning power elite - and the people. The contract required the elites to put limits on their power in return for consent on the part of all the people to allow government to take place. The powers were delegated to an elected legislature that allocated cascading responsibilities for public control over states and localities. The limitations on national government arose from its role to primarily promote and facilitate commerce by individuals among the states and beyond the nations borders (Lowi, 1995).

An important distinction in any discussion of government and its role in American democracy are the terms public and private. For example, a private business or nonprofit organization can provide a service for government via contracted services. In those instances, considerable fuzziness exists as to whether business enterprises or nonprofits that act in place of government or at the side of government are simply operating under the umbrella of government or acting as government. 
Barry Bozeman suggested that public-ness is based on the degree to which an organization is influenced by government and market factors (1987). An important essay by Stephen R. Smith and Lipsky (1993) described the phenomenon of government contracting with nonprofits to provide vital public services and the changes on the culture, operations and values systems of these private organizations, effectively blurring the line between public and private, government or nonprofit. Dennis Young took this line of thinking further in arguing that nonprofit organizations have a role for which they may be defined through their relationship with government. Young offered that nonprofits serve as supplement, compliment or advocate against government (2000).

\section{Business}

The discovery and exploitation of the resources of nature, skilled crafts, trades and industrial production, commerce, and the movement of goods and services were activities that stimulated the Old World to exploit the New World. The earliest enterprises in America were meant to stimulate wealth for investors who sent the first groups of settlers to Jamestown Virginia. History informs us then, that government in American was conceived as tool to promote and sustain commerce and business enterprise. Consequently, risk and reward are at the heart of the American political tradition.

Business forms the basis for everything American. Long ago, it was the reason for the discovery, exploration, and Old World settlement founding of the country. Business enterprise provided the rationale for the risk taking ventures that led to the American revolution and the growth and development of American democracy, association and civil society. Business interests shaped the Constitution of the United States and provided the motivation immigration and the advancement of quality-of-life for individuals and families. 
Simply, a business in America is a formal enterprise engaged in the provision of goods or services at a profit. Profits can be shared by owners of a business or and industry of businesses to increase individual and collective wealth. Among the more simple forms of business enterprise found in capitalist countries such as the United States are those owned by a single individual or family. Traditionally, families in early America are the primary business owners and operators. Today, family owned business and sole proprietorship comprise the overwhelming majority of American business enterprises (US Census, 2000).

The historian Alfred Chandler wrote that business sector enterprise in America had two distinct periods of development. The first, prior to the 1850s was relatively unregulated and focused on the creativity and energy of individuals serving small communities. According to Chandler, business was dominated by the output of plantations and farms, small mills and skilled crafts-work. After 1850, businesses emerged that took on more a corporate character with complex manufacturing managed by professionals spread across the landscape sometimes at great distance. Today we would recognize these aspects of business enterprise as common characteristics of corporations of all sizes (Chandler, 1977).

The independent profit motive interests of business enterprises in America require an environment of low taxes, reliable and quality public services and minimal regulation by outside authorities which can results in increased costs of carrying out business activity. In this framework for business enterprise, the American Political Tradition exists to achieve the best balance of freedom of business operation and public oversight through regulation to protect the public interest while maintaining the best circumstances to achieve profits and generate wealth.

It is important to appreciate that the pursuit of wealth is a common interest to nearly 
every citizen and resident of the United States, going back to the founding of the nation. If not for the pursuit of wealth through organized business endeavors, American democracy could not exist for as individuals and families who have no tangible assets. Democracy gains is traction in American society because of the belief that residents are not born into a limited life-ling status, but can accumulated wealth and the freedom it buys if they work hard and make smart decisions. In this sense, business and democracy are mutually sustaining components of American life. Nonprofit Organizations

Peter Drucker observed that private nonprofit institutions are central to American society and are its most distinguishing feature (1990). But the term "not-for-profit" or "nonprofit" is a modern invention of the United States government and refers to any one of thirty-two types of tax-exempt private organizations (IRS Publication 557, 1997). These organizations are differentiated by the sub sector of the economy in which they operate, and the IRS distinctions reflect varying degrees of tax exemption and limitations on their charitable works.

Generally speaking, nonprofit organizations are governed by a volunteer board of directors who, as stewards of the organizational mission, serve a custodial role over the enterprise, receiving no monetary or business compensation for their services. Surplus operating funds, donations, grants, fee and endowments income of the organization are reinvested for the betterment of the organization and not distributed to individuals as capital gains or return on investment.

There are many ways to understand what nonprofits are and their role in American democracy. For example, David Horton Smith and Ce Shen have written that voluntary, informal, grassroots associations are a form of nonprofit and are distinguished from governments, businesses, and families by the substantial presence of voluntary altruism. Smith 
and Shen do not differentiate one form of nonprofit from simple association between individuals based upon the budget size or the issue drawing people together. Rather the essence of the definition is through the actions of the association and the formality of its work. Smith and Shen also note that small community based nonprofits contribute to political pluralism, participatory democracy and permissive political control that in turn sustain civil society (2002).

In his primer on the nonprofit sector Lester Salamon refers to the private nonprofit sector as the set of organizations that are privately incorporated but serve a public purpose (Salamon, 2002). We learn from Salamon that in America, nonprofit organizations predated the state because communities formed before government institutions were in place to help deal with common concerns. This use of informal associations was the means of establishing social and economic norms and ultimately civil society in America. Over time, formal private institutions have come to sustain civil society and democracy.

In the Nonprofit Economy (1981) Burton D. Weisbrod noted the limitations of government and private enterprises place the unique characteristics of nonprofits in an important role to serve important social aims that neither the other two can serve well. In a democratic society in which government tends to serve the needs of the majority, nonprofit institutions can respond to the demands of people who feel intensely about special interest activities.

The considerable increase in contracting services by government with nonprofit providers since the 1980s has been well documented. Steven R. Smith and Michael Lipsky (1993) express the view that contracting with nonprofits dramatically changed the way public policy was realized, and that nonprofits were significantly changed by their relationship with government to deliver social welfare services. In very simple terms, private organizations that are contracted by 
government to perform public services are obligated to follow the operational rules and regulations for accountability of taxpayer supplied funds. Maintaining compliance with government regulations adds costs and complexity to private organizations, that might otherwise not have been necessary.

Dennis R. Young picks up on this theme of partnership between government and private nonprofit organizations and informs us that nonprofits can be founded and designed to serve government. Young suggested that nonprofits can serve as a supplement or complement to public services and authority. At the same time, they also serve as advocate for change through the act of feeding back information to government based upon the work performed (2000).

Walter Powell and Elisabeth Clemens have noted that nonprofit organizations exist in a gray area, straddling government and the market place. They appear to be neither commercial nor governmental and yet are partially sheltered by government from market forces and subsidized in part by government funding. Whether they should be tax exempt, are autonomous from government and provide services to benefit the public good are issues of great concern to donors, policymakers and governments (Powell \& Clemens, 1998).

In performing the work of government and providing a link to associational life in America, nonprofit organizations serve as prime agents for advocacy with public authority and in informing private interests. Nonprofits have a responsibility and provide the societal mechanism to feed information back into the system of policy makers, grant makers and philanthropist working to solve political, economic and social problems, and decision makers over the public good.

The role of nonprofit as advocate between the sectors of American society is a function of democracy that is not readily found elsewhere on the globe. As mediating or bridging 
organizations, nonprofits inform and allow political minorities to influence decision makers in government and protect the rights of individual citizens against unrestrained, unmonitored business activity while preserving the environment for business enterprise. In simplest terms, nonprofits moderate tension at the boundaries of government and the market, wherein services, planning and mediation are necessary to sustain an American political tradition that rewards individualistic effort, the creation of wealth and limited government. Through the process of private action, nonprofits promote involvement by individuals in the regulation of government, business and other nonprofits, using franchise of democracy.

\section{Family}

John Gardner, the influential founder of the Independent Sector, former secretary of the department of Health Education and Welfare (HEW) in the administration of Lyndon B. Johnson, and a well known speaker on the topics of leadership in American life, noted that each generation of caring citizens must take action to recreate and reshape their society to meet the unrolling future. (Gardner, 2003). The social historian Arthur M Schlessinger, Sr, devoted an entire chapter in his final work "The Birth of Nation," to the role of the American family (1968), crediting the American family as the basis for sound community life made more urgent by economic need during the country's formative years.

The theme of family resonates throughout American history as an anchor of civil society and social norms. Although traditional notions of family have been revised over the second half of the twentieth century to account for the high incidence of divorce, single parent families, children raised by grandparents, domestic partnerships and the like, the family as a basic organizing structure and the transfer of values from parental figures to children and youth still 
hold fast in importance to American democracy.

It is worth noting that inter-connections between groups of people begin with family relationships and the social values and work ethics each contributes to their associations with others. American democracy requires civic engagement by individuals and through an ecology of games contributes to the public social policy debate. In other words, the smallest association of people, the family, forms the basis for participatory democracy.

Peter L. Berger and Richard John Neuhaus, writing under the banner of the conservative American Enterprise Institute, authored an influential book called To Empower People: The Role of Mediating Structures in Public Policy, asserting that one way to increase public welfare services without increasing the size of government was through the use of mediating organizations. Berger and Neuhaus defined mediating organizations as structures which stand between individual people and impersonal institutions. The posited mediating structures listed in To Empower People were the neighborhood, the family, the church and the voluntary association.

Neighborhoods, families, churches and voluntary associations as mediating structures were mentioned for three reasons. First, the mediating structures enveloped the endorsement of many ideologies concerned with community by classical thinkers such as Edmund Burke, Alexis de Toceque-ville, Karl Marx and Emile Durkheim. These mediating structures were transforming dramatically in America throughout the 1950s, 1960s and 1970s as reflected by the post WW II baby boom, suburbanization, the decline of major American industrialized cities and the rise of others. Second, the mediating structures sat at the center of Great Society War-OnPoverty programs which called for "maximum feasible participation" which played important roles in civil and welfare rights and social justice initiatives. Third, Berger and Neuhaus's 
mediating structures provided rallying points (Fisher,1994) during the 1960s and 1970s for people who had begun to question the size of government and its role in the welfare state in an American society (Smith \& Lipsey, 1993) committed to private property, low taxes and individualistic effort.

Practically speaking, the neighborhood, the family, the church and the voluntary association readily amassed grassroots support by people in city neighborhoods for civil and welfare rights advocacy and wealth preservation in community organizing (Thomas, 1986; Peirce, 1980; Banfield 1970, 1974). As a result, private nonprofit neighborhood organizations were positioned to work on behalf of their constituents with the public sector. As Berger and Neuhaus pointed out, formal associations of people provide an institutional mechanism to hold government, business and others accountable through democratic action.

Most relevant for nonprofit executives were the characteristics Berger and Neuhaus assigned their mediating structures. Borrowing from Burke, they suggested that the "small platoon" was an effective way to assuage the alienation people felt against their public institutions and to bridge the gap between public policy and best practice. Neighborhood based organizations allowed for innovative problem solving. Private organizations were adaptable to changing circumstances. Mission driven nonprofit organizations had board membership from the neighborhood which was accessible to people close to the problems at hand.

\section{Summary: American Democracy and Civil Society Discussion of future directions}

There is much to be learned about the nature of civil society and democracy in America. Terms such as democracy, civil society, government, business, nonprofits and the family are familiar and yet much more complex than we may credit at first glance. Numerous scholarly journals produce even more numerous articles that struggle to pin down these surprisingly 
elusive concepts.

It is also no coincidence that the terms democracy and civil society are often paired in scholarly discourse. The credibility of democracy arises from the trust individuals have in the system and the seriousness with which they take their responsibilities for voting, associating, and maintaining a health oversight of public and private matters (Skocpol \& Fiorina, 1999). The interconnections between Americans and their tendency to organize around issues of all kinds, lays the groundwork for trust in society. Robert Putnam's research connecting effectiveness of democracy in Italy to the presence and vibrancy of voluntary associations in Italy illustrates this principle quite clearly (Putnam, 1993).

Four reinforcing facets of this discussion stand out as useful tools that students of American democracy may use to inform their understanding of the interconnections between government, business, nonprofits and families. First, the engagement of individuals, families, businesses, nonprofits and government officials in an ecology of games in a local community is necessary to form bonds of partnership necessary to sustain democracy. These inter-connections form the fabric of civil society and allow communities to solve public problems by private means. Second, multiple constituencies influence the goals and objectives of government, business, nonprofits and families as they contend with other players in the ecology of games. Third, individuals, families, businesses, nonprofits and government officials that are characterized by flexibility of action, organization structure and entrepreneurism makes them extremely attractive as partners. This characteristic promotes democracy and its evolution to meet new challenges in the United States. Fourth, associations minimize atomistic concerns of people, improve opportunities for wealth, protect the rights of people from the tyranny of uncheck authority and business, and nurture the institutions of civil society. 


\section{References}

Ashcraft, R. (1986). Revolutionary Politics \& Locke's Two Treatises of Government. Princeton: Princeton University Press.

Bailyn, B. (1992). The Ideological Origins of the American Revolution. Cambridge: Harvard University Press.

Beetham, D. (1991). Max Weber and the Theory of Modern Politics. ( $2^{\text {nd }}$ Edition). London: Allen and Unwin.

Berger, P.L., \& Neuhaus, R.J. (1977). To Empower People: The Role of Mediating Structures in Public Policy. Washington, D.C. American Enterprise Institute for Public Policy Research.

Bozeman, B. (1987). All organizations are public: bridging public and private organizational theories. San Francisco: Jossey Bass Publishers.

Chandler, A.E. (1977). The Visible Hand: The Managerial Revolution in America Business. Cambridge, Ma: Belknap Press of Harvard University Press.

Dahl, R.A. (1985). A Preface to Economic Democracy. Berkeley: University of California Press.

de Tocqueville, A. (2000). Democracy in America. Chicago: University of Chicago Press.

Drucker. P.F. (1990). Managing the Nonprofit Organization: Principles and Practices. New York: Harper Collins.

Electoral Democracies (123). (2007). Washington DC: Freedom House Inc.

Fisher, R. (1993). Mobilizing the Community: Local Politics in the Era of the Global City. Thousand Oaks, Ca: Sage Publishers. 
Gardner, J. (2003). Living, Leading and the American Dream. San Francisco: Jossey Bass Publishers.

Gould, L. (2003). Grand Old Party: A History of the Republicans. New York: Random House.

Hammack, D.C. (Ed.). (1998). Making the Nonprofit Sector in the United States: A Reader. Bloomington: Indiana University Press.

Hofstadter, R. (1948). The American Political Tradition and the Men Who Made It. New York: A. A. Knopf.

IRS Publication 557 (1997). Tax Exempt Status for Your Organization.

Long, N.E. (1958). The Local Community as an Ecology of Games. The American Journal of Sociology, 64(3), 251-261.

Lowi, T. (1995). The End of the Republican Era. Norman, Okla: University of Oklahoma Press.

James Madison, The Federalist No. 10.

Nackenoff, C. (2005). Locke, “Alger and Atomistic Individualism Fifty Years Later: revisiting Louis B. Hartz's Liberal Tradition in America." Studies in American Political Development, 19, 206-215.

O'Connell, B. (1999). Civil Society: The Underpinnings of American Democracy. Medford, MA: Tufts University Press.

Powell, W.W. \& Clemens, E.S. (1998). Private Action and the Public Good. New Haven: Yale University Press.

Putman, R. (1993). Making Democracy Work: Civis Traditions in Modern Italy. Princeton, N.J.: Princeton University Press. 
Rosenblum, D.H. (2004). Pubic Administration 6th Edition. New York: McGraw Hill Higher Education Publishers.

Schlessinger Sr., A.M. (1968). The Birth of the Nation: A portrait of the American People on the Eve of Independence. New York: Alfred A. Knopf.

Skocpol, T. \& Fiorina, M.P., (Ed.). (1999). Civic Engagement in American Democracy. Washington D.C.: Brookings Institution Press.

Smith, D.H. \& Shen, Ce. (2002). The Roots of Civil Society: A Model of Voluntary Association Prevalence Applied to Data of Larger Contemporary Nations. International Journal of Comparative Sociology, 43 (2), 93-133.

Smith, R. (1993). "Beyond Tocqueville, Myrdal and Hartz: The Multiple Traditions in America." American Political Science Review, 87(3), 549-566.

Smith, S.R. \& Lipsky, M. (1993). Nonprofits for Hire: The WelfareState in the Age of Contracting. Cambridge, Mass.: Harvard University Press.

Ubbelhode, C. (1961). Vice Admiralty Courts and the American Revolution. Chapel Hill: University of North Carolina Press.

Weisbrod, B.D. (1991). The Nonprofit Economy. Cambridge: Harvard University Press. Wood, G.S. (1991). The Radicalism of the American Revolution. New York: Vantage Books. Young, D.R. (2000). Alternative Models of Government-Nonprofit Sector Relations: Theoretical and International Perspectives. Nonprofit and Voluntary Sector Quarterly, 29(1), 149-172. 


\section{Further Reading}

Boris, Elizabeth T. and Steuerle, Eugene C. editors. Nonprofits \& Government:

Collaboration \& Conflict. Washington, D.C.: Urban Institute Press, 2006.

Bozeman, Barry. Public Values and Public Interest: Counterbalancing Economic Individualism. Washington, D.C.: Georgetown University Press, 2007.

Chandler, Alfred Dupont. Shaping the Industrial Century: The Remarkable Story of the Evolution of the Modern Chemical and Pharmaceutical Industries. Cambridge, Mass.: Harvard University Press, 2005.

Drucker, Peter D. Classic Drucker: Essential Wisdom of Peter Drucker from the Pages of Harvard Business Review. Cambridge: Harvard Business Review Book, 2006.

Elliott, Carolyn M., editor. Civil Society and Democracy: A Reader. Oxford : Oxford University Press, 2003

Fisher, Robert. Let the People Decide: Neighborhood Organizing in America. Boston, Mass. : Twayne Publishers, 1984.

Kramnick, Issac and Lowi, Theodore J., eds. American political thought: a Norton anthology. New York : W.W. Norton, 2009.

Mendel, Stuart C. Mediating Organizations, Private Government and Civil Society: Disinvestment through the Preservation of Wealth in Cleveland, Ohio (1950-1990). Lewiston: Edwin G. Mellen Press, 2007.

O'Connell, Brian, Fifty Years in Public Causes: Stories from a Road Less Traveled. Medford, Mass.: Tufts University Press, 2005. 
Powell, Walter and Steinberg, Richard. The Nonprofit Sector: A Research Handbook, Second Edition. New Haven: Yale University Press, 2006.

Putnam, Robert D. Bowling Alone: America's Declining Social Capital. Baltimore: Johns Hopkins University Press, 1996.

Rosenbloom, David H. Democratic Constitutionalism and the Evolution of Bureaucratic Government: Freedom and Accountability Urbana : University of Illinois Press, 1992.

Sandel, Michael. The Public Philosophy of Contemporary Liberalism. Belmont, CA : Wadsworth/Thomson, 2003.

Shane, Scott. The Illusions of Entrepreneurship: The Costly Myths that Entrepreneurs, Investors and Policy Makers Live By. New Haven: Yale University Press, 2008.

Skocpol, Theda and Jacobs, Lawrence R. editors. Inequality and American Democracy What We Know and What We Need to Learn. New York: Russell Sage, 2005.

Stanton, Thomas. Government-Sponsored Enterprises Mercantilist Companies in the Modern World. Washington, D.C.: AEI Press, 2002.

Van Til, Jon. Growing Civil Society. Bloomington: Indiana University Press, 2000.

Wood, Gordon S. The Americanization of Benjamin Franklin. New York: Penguin Press, 2005.

Young, Dennis R. and Hollister, Richard. Governing, Leading, and Managing Nonprofit Organizations: New Insights from Research and Practice. Newark, NJ: Jossey Bass Nonprofit \& Public Management Series, 1992. 
Young, Dennis and Salamon, Lester. Commercialization, Social Ventures, and For-Profit Competition. Washington, D.C.: Brookings Institution Press, 2002.

\section{Biography}

Stuart Mendel is the Assistant Dean for the Maxine Goodman Levin College of Urban Affairs, and Co-Founder and Co-Director of the Center for Nonprofit Policy and Practice. He received a Ph.D. Social Policy History and a Master of Nonprofit Organizations from Case Western Reserve University in 2000 and 1991 respectively, and a bachelors of arts in geology and geography from Miami University of Ohio in 1983. His research interests include the nature of the nonprofit sector, uses of nonprofit organizations in civil society, social capital, private/public partnerships, the political capacity of nonprofit organizations and urban history. 